\title{
THE APEX OF THE FETISHISM: ADMINISTRATION, EDUCATION AND SOCIAL CONTROL 1
}

\author{
Maxilimiano E. Korstange ${ }^{2}$ \\ University of Palermo, Argentina \\ Jean Henrique Costa ${ }^{3}$ \\ Universidade do Estado do Rio Grande do Norte - UERN \\ Thadeu de Sousa Brandao ${ }^{4}$ \\ Universidade Federal Rural do Semiárido - UFERSA \\ Tássio Ricelly Pinto de Farias ${ }^{5}$ \\ Faculdade Evolução do Alto Oeste Potiguar - FACEP
}

http://dx.doi.org/10.5209/NOMA.54865

Abstract.- This paper discusses, as an essay configuration, the way by which the socalled "scientific management" fits in a socio-technical schemeof creation and ideological reinforcement in favor of the Capital and its reproduction. Through Marxist tradition, starting at ideology's standpoint in Marx and through contemporary authors such as Adorno, Horkheimer, Marcuse, Fromm, Mészáros and Žižek, it is intended here to show how the allegedly administration scientific discourse provides mechanisms for full fetishization and reification of the subject, making it docile instrument of control of the Capital and maintenance and reproduction of the capitalist order.

Keywords: Administration; Ideology; Fetishism; Domination.

Over recent years, some specialists considered that there would, broadly speaking, two basic forms of deluding. On one hand, we may fall subject, conscious or not some ideas struck our mind come from external sources, but are right for us. Otherwise, on another, at least not in full plenitude some beliefs, ideas, or stereotypes which contradicts our psychological cognitive structures, can be rejected by lack of credibility. This is the reason why, we held the thesis, in this short essay review, that the "school of Administration", already dubbed by Frederich Taylor, as Scientific Administration, is in consonance within a rationalized ethos of

\footnotetext{
1 Translated by Hionne Mara da Silva Câmara and reviewed by Maximiliano E. Korstanje 2 Fellow at CERS Universidad de Leeds UK. Reader at University of Palermo, Argentina. Email:mkorst@palermo.edu

3 Sociólogo e Doutor em Ciências Sociais. Professor da Universidade do Estado do Rio Grande do Norte - UERN. E-mail: jeanhenrique@uern.br

${ }^{4}$ Sociólogo e Doutor em Ciências Sociais. Professor da Universidade Federal Rural do Semiárido - UFERSA.

5 Filósofo e Mestre em Ciências Sociais e Humanas (UERN). Professor da Faculdade Evolução do Alto Oeste Potiguar - FACEP. E-mail: tassioricelly@gmail.com
} 
socio-technical reinforcement of ideologies, which bespeak in the name of capital. To put this in other terms, the individual emancipation appeals to "common sense" which is organized into a reified atmosphere fabricated by capitalist fetishism. Regardless the academic wave, administrative models rests on the deluding as a path-grounding instrument, voluntarily or not, of control. In this essay review, four of these models will be placed under the critical lens of scrutiny. The first family of theories signals to "the management of peoples", whose main goals was oriented to give talents to companies and financial corporations, oddly considering manpower as a simple alienable resource to be ordered using rationale. Marxism has posed some critical notes at time of considering alienation serves not only to the interests of capital-owners, but produces a false-consciousness in workforce, because they do not reach what they really want.

Marx (1983, p. 263) already demonstrated that the directing motive, the end and aim of capitalism production, is to extract the greatest possible amount of surplus-value, and consequently to exploit labour-power to the greatest possible extent. Therefore, the exploitation of work is structural in the capitalist production. A supposed human management in work, in this sense, operates at most as the spent effort in the attempt of transforming work, from irreconcilable adversary to a docile accomplice of the capital (MÉSZÁROS, 2002).

As this backdrop, Marcuse (1973, p. 47) acknowledges that in the current society, technology serves to institute new, more effective, and more pleasant forms of social control and social cohesion. Thus, the mechanisms of administration and domination advance silently and, the worst, become each day more effective and imperceptible: advance over unconscious. Henceforth, workers not only do not internalize the needs to overrise the interests of owners, but have not forged their own programs or goals to be achieved. As it was formulated in capitalist culture, the management-review rests on the needs workers obey as automats and robots instead of proposing a new synergic discourse. This was the reason behind Max Horkheimer and Theodor W. Adorno have lost their enthusiasm in the possibilities to conduct an evolving proletarian revolution: since working-classes had lost its revolutionary conscience, the derived domination tends to reduce the conflict into a minimum expression. Alienated workers not only are unfamiliar with the state of deprivation they are subject, but also in some conditions they feel happier by the introduction of mass consumption and commoditization (MARCUSE, 1973, p. 84). All resources are unfolded to undermine the resistance of manpower to the text that top managers are evaluated according to their skills to seduce workers into an ideological allegory. In this vein, Dourado and Carvalho confirm that that quality life intersects with centralized programs in decision making process. While incentive programs motivate workers to feel they are part of something important, 
the fact is that it juxtaposes an alienated man with exploitation. In this context, the system of rewards delineates the borders to discipline the ingroup members drawing the necessary ideological apparatuses in order for surveilling the others, combining instrumentalization with satisfaction. (DOURADO; CARVALHO, 2006). Quite aside from any ethical discussion, capitalism do not trust in the other, and need from all available instrument to ensure a pervading control.

In the words of Padilha (2010), these life quality programs at work (QVT) become a 'mean' to cover problems of structural order (in the organization and society); to reinforce an ideology of 'bread and circuses' and to focus in the individual, deflecting the attention of what treats of a capital's social metabolism problem. In this way, thinking people management is, overall, thinking of forms in which capital manages its extended reproduction. The worker labels as "collaborator" serve strongly as strategy of flexibility and, therefore, precariousness of workforce. As Adorno puts it, capitalism reminds that consumers are disciplined as docile slaves who abdicate their wills into the illusion only consumption grants. Therefore, the profit-oriented programs which are fixed to maximize capital, needs for ideology to keep the group working. In other terms, whenever workers feel exploitation, conflict surfaces. Doubtless, capital-owners allude to leisure consumptions to absorb part of their wages. At the time the economy expands, further leisure consumption forms as tourism or the industry of cultural entertainment emerge. In that way, conflicts did not take pathological levels to become in confrontation. Adorno envisioned this, when confirmed that cultural industry was in next to transform in a great Advertisement. What can be sold or exchanged in the marketplace, not only corresponds with the capital each worker has, but also the worker becomes in a commodity as well. As this argument given, the instrumentalization of labour is codetermined by the reified style of consumption the society offers. While the workers enter in the pipeline of exploitation in quest for a salary, it is absorbed by the introduction of leisure and tourism.

Since work has been (or has always been) seen as a mean to an endunderstanding this end by consumption - little by little the workers are being convinced that their work conditions are improving simply because they are consuming more. What they forget is that this mechanism aims exactly the maintenance of their real states of consuming workers. For example, we have the case of employees that receive at the end of the year the called PL (profit participation), that would be no more than a strategy to make all "collaborators" work harder, so they can earn more and, consequently, consume more. It is observed that, as said by Adorno and Horkheimer (1985), the workers insist increasingly in the ideology that slaves them, that is the consumption. However, delusions do not cease, but rather they are replicated in the application of management programs. Supported by 
marketers, top management signals to the imposition of needs in order for workers to be far from what they really need. Paradoxically, capitalism expanded successfully worldwide thanks to two main tenants. The first and most important, was the psychological need which liberated the ties of Medieval peasants, but at the same time, they changed substantial the theory of economy which claimed that consumption was a bad thing for sustainability. In that way, through 60s decade, capitalism passed from a society of producerist to a society of consumers. Although the problem of poverty oriented an historical struggle against the aspects that threatens the production, no less true was that the system of production mutated to new forms, where production sets the pace to consumption. In this background, we come across with a consuming culture which reinforces a complementary cultural value to the current state of exploitation, joy. The imperative is that one must consume, buy, eat, drink, having sex, to reach an eternal happiness. In Erich Fromm's account (1965) the fear of being free is conducive to the renounce of the right of being "conscientious" of the pain. The quest for the pleasure-led maximization plays a vital role in the well smooth functioning of capitalism, which expands minimizing costs and maximizing produced wealth. Faster but not for this egalitarian, capitalism in Fromm's mind fabricates alienated consumers instead of free citizens.

As well said by Marcuse (1973, p. 56):

Most of the prevailing needs to relax, to have fun, to behave and consume in accordance with the advertisements, to love and have what others love and hate, belong to this category of false needs [...] Such needs have a societal content and function which are determined by external powers over which the individual has no control; the development and satisfaction of these needs is heteronomous.

Unless otherwise resolved, in the late capitalism, subjects are pressed to consume commodities not only they do not need, but also producing a gap between they and their institutions. The capacity of manipulation of wishes and creation of justifications on behalf of capitalism has been one of the big ideological weapons of the $21^{\text {st }}$ century. In this sense, the promotional marketing became a strong allied in this ideological war pro-capitalism. Let's remember that Marx, in The Capital, exposes the phantasmagoric character of commodity in capitalism, system which produces it. Describes, through the concept of "commodity fetishism", how social relations become mediated by "things". The fetishism brings out an illusion that we are mediated by people, when in fact commodities do that for us. This relation becomes substantial and imperceptible, at least directly. Meanwhile, the consumption becomes 
the great mediator of social relations. According to Milton Santos (2003), consumption - narcissism vehicle - becomes the great fundamentalism of our time, exactly because it achieves and involves everyone. Nobody or almost anybody escapes from this process. We transform our Christmas in the party of buying presents. Our Easter? Party of chocolate eggs. Mother's, father's day, etc.? Presents to be bought. We mediate our love through presents, properly produced by industry. Besides, it is not enough to be a commodity, it has to integrate its own esthetic of brands and models. I am going to buy margarine in the supermarket? It has to be $X$ or $Y$. Discounting the embedded profit, costs and other constitutive elements of the final commodity value. What is left? The fetishism, that extends the process increasing an esthetical, visual and, thus, purely cultural and social character. After all, it is not enough to have a cell phone: it's necessary an IPhone model. We buy in our everyday life without needing products that we will rarely or never use. We stock clothes, perfumes, shoes, watches, house and electronic trinkets... We buy them! After all, if our social relations are measured be the consumption of commodities, it is only by this process that commodities accomplish themselves as such. Once they are bought? Lose their never existing before utility. To us, occurs new anxiety and emptiness, only fulfilled with new consumption. At the end of the day, if these false needs are what "perpetuate the toil" (MARCUSE, 1973, p. 56), when are we going to decide by ourselves to give them up? To Marcuse (1973, p. 57), this question "[...] must be answered by the individuals themselves [...], if and when they are free to give their own answer. As long as they are kept incapable of being autonomous, as long as they are indoctrinated and manipulated [...] the answer to this question cannot be taken as their own". Meanwhile, the systematic assault pro-consumption advances over unconscious, creating artificial needs in the subjects and consequently, products to satisfy them. The contemporary subject gets increasingly more impotent ahead this total administration of culture by capital. The capacity to consume is proportional to desinversion of economic system. Since consuming leads to virtual exchange, where money even is not passed from hands in hands as in earlier times, but is figured symbolically into abstract systems such as credit cards, or electronic payments, so we might speculate that capitalist needs from abstraction to discipline workers. This is exactly the claims of Slavoj Žižek respecting to the possibility to live in Matrix, in allusion to the well famous saga:

The 'totalitarian' notion of the 'administered world', in which the very experience of subjective freedom is the form of appearance of subjection to disciplinary mechanisms, is ultimately the obscene fantasmatic autonomy and freedom: the first has to accompany the second, supplementing it as its obscene shadowy double, in a way 
which cannot fail to recall the central image of the Wachowski Brothers' film Matrix (ŽIŽEK, 2003, p. 96).

At some extent, Žižek points us that capitalism is the first socioeconomic order that monopolize the meaning: in other words, it is also not global by the level of meaning (in capitalism there is not, for instance, a "capitalist world view" global nor an intended "capitalist civilization"; the fundamental lesson of globalization would be exactly that the capitalism itself can adapt to all civilizations, from the Christian to Hindu or Buddhist). "The problem is one of meaning, and it is here that religion is now reinventing its role, rediscovering its mission of guaranteeing a meaningful life to those who participate in the meaningless functioning of the capitalist machine" (ŽIŽEK, 2011, p. 25). To what religion are meaning Žižek? The system that most enchanted its subjects with dreams (of freedom, that success depends only of us, of the lucky hit of success right on the corner, of the limitless pleasures) was capitalism. As he himself described: "it's ideology, stupid!".

In the ideological version of capitalism that imposes currently, we realize the emergency of a vision of a "socially responsible" capitalism. Admitting that, during its formation and even today, free market capitalism many times was over-exploiter, with catastrophic heritages, this version now says that we can distinguish the signs of a new conscious via that "the capitalist mobilization of a society's productive capacity can also be made to serve ecological goals, the struggle against poverty and other worthy ends" (ŽlŽEK, 2011, p. 34). According to Žižek, the vision that makes homogeneous is that capitalists should not be only profit making machines; after all, its life can have a deeper meaning. Thus, his favorite mottos turn to be gratitude and social responsibility.

The new ethos of global responsibility is thus able to put capitalism to work as the most efficient instrument of the common good. The basic ideological dispositive of capitalism - we can call it "instrumental reason", "technological exploitation", "individualist greed", or whatever we like - is separated from its concrete socio-economic conditions (capitalist relations of production) and conceived of as an autonomous life or "existential" attitude which should (and can) be overcome by a new more "spiritual" outlook, leaving these very capitalist relations intact. (ŽIŽEK, 2011, p. 35).

What Žižek tries to show is still a bigger proof of vitality of the Marxist concept of reification. Lukács reinforces that as capitalism produces and reproduces itself incessantly, the reification penetrates the structure of 
human conscience in a deeper way. Advancing in the art of deluding, the culture entrepreneurship, which emphasizes on creativity to the remedy of all evils, triggered by the ideology of Managers, leads today towards a complete unhappiness. Given this discussion, the quest for goal achievement as well as the climate of social Darwinism where fewer have a lot but the majority dies with nothing, capitalism has cruelty replicated serious material asymmetries among classes (Korstanje 2015). For those who had not success in competing with others at the liberal market, the concept of risk plays a major role in providing the reason that explains failure as a sign of proper incapacity. That people should and can undertake freely we see no objection. However, there are indeed perverse effects in the nature of this advice. As well demonstrated Lima (2008), the defense of entrepreneurship, while an escape to the "losers" of globalization, finishes by propagating a message for the workers (formal and informal) that says: the unadjusted need to adjust. Promptly, in a scenario that unemployment and precariousness are growing phenomena, the winners start to be, ideologically, entrepreneurs, the acceptance to face all risks to come (Korstanje, 2015). What Lima evinces, is exactly the concerns how the culture of entrepreneurship ignores the socio-economic background where risks upsurge, leaving behind those workers who are not in condition to mitigate the negative effects of risks that are generated by higher classes. The needs of adopting a discourse of creative destruction gives less attention to structural problems that determined poverty, but defines poverty as the results for the lack of entrepreneur spirit. To cut the long story short, we are confident that there is no room to the precarization of working conditions, as well as the lack of fairer wealth distribution in the economic programs but the fact is that workers do not coordinate efforts thinking they are part of privilege peoples, who given some conditions will win. Korstanje, in earlier studies, pivoted this belief considering the capitalist system as movies of Hunger games where participants struggle with others in quest of the glory. They, far from coordinating efforts to defy the status quo, exaggerate their possibilities to defeat, while competence reinforces the center-periphery dependence (Korstanje, 2015a; 2015b; 2015c). In this respect, as Marcuse observed (1973, p. 53), "Freedom of enterprise was from the beginning not altogether a blessing. As the liberty to work or to starve, it spelled toil, insecurity and fear for the vast majority of the population". Last but not least, the last resource for deluding corresponds with the financial administration. As a great weapon in favor of maneuvers in order to disguise the bills and reduce to the most the cost with taxes or other expenses, financial administration reproduces the basis for a speculative character, which ushers into greed. As a result of this, many entrepreneur businessmen not only devote their legal resources to evade taxes, but also commit illegal acts in quest for profits. The so-called creative accountancy, growing today in both public administration and 
in financial management companies, means a sort of makeup of patrimonial reality of an entity, due to financial data manipulation in intentional form, to present the wished image by the managers of posting information (OLIVEIRA, 2010). To wit, Oliveira also mentions that some examples of such practice are shortening the costs with personal, by means of hiring outsourced services that evolve personal spends, accounting launched as investments, the exclusion of insurance benefits not covered with fund resources of retirement, for instance; delaying payment of fiscal year's functionalism, expenses that could be launched as previous exercises and so on. These accountancy and budget manipulations turned the economic and financial life of the companies and public administration in a sort of black box that hides from society the situation of these institutions that are only known by those who issue orders to be accomplished by technicians that materialize them, but by trade's and job's duties, do not reveal them (OLIVEIRA, 2010). This explains partly the cultural roots of political corruption, which in countries as Brazil, patronized the political class. As discussed, in Brazil, the denominated Brazilian way expresses an entire ethos of being Brazilian, a habitus, in the sense employed by Pierre Bourdieu, is not hard to assume the multiple maneuvers by which financial management of companies and public beings do daily to its transparency and competence. Speculation aside, while we write this small article, certainly hundreds of students register in courses of administration and related around Brazil. We do not blame them. The discourse of success is charming. The search for the scape of the condition of precarious worker is legitimate. And living the dream of a life worthy of consumption is basic condition of any individual. Besides, not all lie is absent of certain positivity to the receiver. For Ceccarelli we are constantly interplead in our daily life by illusions and lies under the most diverse presentations, like promises of success, guarantees of happiness, a possibility of immortality, miracle products, personal relations and others. Even knowing that they are mostly false, they work as a social optical illusion, because they hardly ever fulfill their promises, but at the same time we need them to avoid confrontation with the constitutional abandonment. We know they are lies, but we pretend not to, and that deceptively maintains the social bond (CECCARELLI, 2012).

Philosophically speaking, then, delusions and lies are social constructions that work as catalyst of the order. Consequently, the administration also contributes as a maintainer by the part of the social order. If it was not for it and its rising at work's promises and prosperous consumption, workers and consumer's rebellions would be much more often. What can cause astonishment is not the individual looking for this kind of job, study or advice, but those who feed the alleged idea that administration would be a science in order to construct a rational and fair society. This raises a more than interesting question what are the ethical boundaries of Management in our unjust world? 
It is necessary not to lose the sight that current scientifization of management obscures more than it clarifies. Basically, it technical behaviour leads to the automatization, which reinforces the lack of critique spirit, any science needs. The process of instrumentalization places marketing and management asunder from humanitarian aims. We need a more social marketing which takes persons as the center of its concerns. Well, if "all liberation depends on the consciousness of servitude" (MARCUSE, 1973, p. 58), the administration (as a subject) contributes in nothing for this to occur, since it operates exactly in the attempt of teaching the tricks of administration for some to the detriment of others.

The concept of halb-bildung as it was originally coined by Theodor Adorno, stems from the concern of breaking the symbolic allienation, by the imagination of a new education. In fact, status quo keeps the legitimacy over workforce not only by the values transmitted in educative process, as schools, universities and other establishments, but by the reassessment of beliefs as instrumentalization or competence as the best possible worlds. The current use of technology, if ethics is segregated, will contribute to make a more unjust world. In the words of Milton Santos (2003): a factory of perversity. However, and not all is lost, as reminds Marcuse $(1973$, p. 58) to enclosure this brief essay reflection: "The more rational, productive, technical, and total the repressive administration of societybecomes, the more unimaginable the means and ways by which the administrated individualsmight break their servitude and seize their own liberation". Then, distinctly of what ideology managers would expect, the crushing majority of our constitutive experiences remains out of the scope of formal institutional control and coercion, and will always remain, according to Mészáros; not even the worst shackles have a way to predominate uniformly (MÉSZÁROS, 2008). 


\section{References}

ADORNO, Theodor. O fetichismo na música e a regressão da audição. In. Theodor W. Adorno: textos escolhidos. Tradução de Luiz João Baraúna (revista por João Marcos Coelho). São Paulo: Abril Cultural, 1996. (Coleção Os Pensadores).

; HORKHEIMER, Max. Dialética do Esclarecimento: fragmentos filosóficos. Rio de Janeiro: Zahar, 1985.

CECCARELLI, Paulo Roberto. A mentira como organizador social. Cronos: R. Pós-Grad. Ci. Soc. UFRN, Natal, v.13, n. 1, p. 99-109, jan./jun. 2012.

DOURADO, Débora Coutinho Paschoal; CARVALHO, Cristina Amélia. Controle do homem no trabalho ou qualidade de vida no trabalho? Cadernos EBAPE, vol4. n. 4, dez. 2006.

FROMM, Erich. O dogma de Cristo e outros ensaios sobre religião, psicologia e cultura. 2. ed. Tradução de Waltensir Dutra. Rio de Janeiro: Zahar Editores, 1965.

KORSTANJE, M. E. A Difficult World, examining the Roots of Capitalism. New York, Nova, 2015.

KORSTANJE, Maximiliano E. Reseña de Burúcua (2013). El Mito de Ulises en el Mundo Moderno. Athenea Digital. Revista de pensamiento e investigación social, 2015b, vol. 15, no 3, p. 249-252.

KORSTANJE, Maximiliano Emanuel. Un analisis crítico del Turismo creativo. Gran Tour, 2015c, no 12, p. 2.

LIMA, Aguinaldo Luiz de. Os riscos do empreendedorismo: a proposta de educação e formação empreendedora. Dissertação (Mestrado em Educação), USP, São Paulo, 2008.

LUKÁCS, Georg. A reificação e a consciência do proletariado. In:

História e consciência de classe: estudos sobre a dialética marxista. Tradução de Rodnei Nascimento. São Paulo: Martins Fontes, 2003.

MARCUSE, Herbert. A ideologia da sociedade industrial: o homem unidimensional. Rio de Janeiro: Zahar Editores, 1973.

One-Dimensional Man: Studies in the ideology of advanced industrial society. London; New York: Routledge, 2007.

MARX, Karl. O capital: crítica da economia política. Vol. 1, Livro Primeiro, Tomo 1. Tradução de Regis Barbosa e Flávio R. Kothe. São Paulo: Abril Cultural, 1983.

MÉSZÁROS, István. Para além do capital: rumo a uma teoria da transição. Tradução de Paulo Cezar Castanheira e Sérgio Lessa. São Paulo: Boitempo, 2002.

A educação para além do capital. Tradução de Isa Tavares. 2. ed. São Paulo: Boitempo, 2008. 
SANTOS, Milton. Por uma outra globalização: do pensamento único à consciência universal. 10. ed. Rio de Janeiro: Record, 2003.

OLIVEIRA, Fabrício Augusto de. Contabilidade criativa: como chegar ao paraíso, cometendo pecados contábeis - o caso do governo do Estado de Minas Gerais. XIV Seminário sobre Economia Mineira, CEDEPLAR, Diamantina, $2010 . \quad$ Disponível em: http://web.cedeplar.ufmg.br/cedeplar/site/seminarios/seminario_diama ntina/2010/D10A099.pdf. Acesso em: 10. dez. 2014.

PADILHA, Valquíria. Qualidade de vida no trabalho num cenário de precarização: a panaceia delirante. Trab. Educ. Saúde, Rio de Janeiro, v. 7 n. 3, p. 549-563, nov.2009/fev. 2010.

ŽlŽEK, Slavoj. Bem-vindo ao deserto do real: cinco ensaios sobre o 11 de Setembro e datas relacionadas. Tradução de Paulo Cezar Castanheira. São Paulo: Boitempo, 2003.

Welcome to the desert of the real! Five essays on september 11 and related dates. London; New York: Verso, 2002.

. Primeiro como tragédia, depois como farsa. Tradução de Maria Beatriz de Medina. São Paulo: Boitempo, 2011.

First as tragedy, then as farce. London; New York: Verso, 2009. 